\title{
Integrating livelihoods and conservation in protected areas: understanding the role and stakeholder views on prospects for non-timber forest products, a Bangladesh case study
}

\author{
Sharif Ahmed Mukul ${ }^{\mathrm{a} *}$, Mohammad Belal Uddin ${ }^{\mathrm{a}, \mathrm{b}}$, A.Z.M. Manzoor Rashid ${ }^{\mathrm{a}, \mathrm{c}}$ and Jefferson Fox ${ }^{\mathrm{d}}$ \\ ${ }^{a}$ Department of Forestry and Environmental Science, School of Agriculture and Mineral Sciences, Shahjalal University of Science and \\ Technology, Sylhet, 3114, Bangladesh; ${ }^{b}$ Department of Biogeography, University of Bayreuth, Bayreuth, Germany; ${ }^{c}$ Centre for Biodiversity \\ Management, Swedish University of Agricultural Sciences, Uppsala, Sweden; ${ }^{d}$ East-West Center, Honolulu, Hawaii, USA
}

\begin{abstract}
Protected areas (PAs) represent a key global strategy in biodiversity conservation. In tropical developing countries, the management of PAs is a great challenge as many contain resources on which local communities rely. Collection and trading of non-timber forest products (NTFPs) is a well-established forest-based livelihood strategy, which has been promoted as a potential means for enhanced conservation and improved rural livelihoods in recent years, even though the sustainability or ecological implications have rarely been tested. We conducted an exploratory survey to understand the role and stakeholder views on conservation prospects and perceived ecological feasibility of NTFPs and harvesting schemes in a northeastern PA of Bangladesh, namely the Satchari National Park. Households $(n=101)$ were interviewed from three different forest dependency categories, adopting a stratified random sampling approach and using a semi-structured questionnaire. The study identified 13 locally important NTFPs, with five being critically important to supporting local livelihoods. Our study suggests that collection, processing and trading in NTFPs constitutes the primary occupation for about $18 \%$ of local inhabitants and account for an estimated $19 \%$ of their cash annual income. The household consensus on issues relating to NTFPs and their prospective role in conservation was surprisingly high, with $48 \%$ of respondents believing that promotion of NTFPs in the PA could have positive conservation value. The majority $(71 \%)$ of households also had some understanding of the ecological implications of NTFP harvesting, sustainability (53\%) and possible management and monitoring regimes (100\%). With little known about their real application in the field, our study suggests further investigations are required to understand the ecological compatibility of traditional NTFP harvesting patterns and management.
\end{abstract}

Keywords: forest-based livelihood; biodiversity loss; rural poverty; ecological consensus; harvesting pattern; sustainability

\section{Introduction}

Globally protected areas (PAs) have long represented a key conservation strategy in the face of rapid forest and biodiversity loss (Abakerli 2001; Nagothu 2003; Ormsby and Kaplin 2005; Clerici et al. 2007; DeFries et al. 2007) and are considered the most effective measure for conserving wild biodiversity in situ (Pimbert and Pretty 1997; Mulongoy and Chape 2004). Generally, PAs are 'areas especially dedicated to the protection and maintenance of biological diversity and associated cultural resources, which are managed through legal or other effective means' (IUCN 1994). Over the past few decades, the number and coverage of PAs has increased dramatically in most regions of the world (McNeely and Scherr 2003; Kaimowitz and Sheil 2007), and presently there are more than 100,000 PA sites worldwide, covering nearly $12 \%$ of the land surface (Chape et al. 2003; Scherr et al. 2004; Wells and McShane 2004). Many tropical developing countries, where biodiversity is presumably greatest and where local communities rely on it for sustaining livelihoods, have also expanded markedly their amount of land under PAs, as an attempt to address growing concerns on conservation (Ghimire 1994; Koziell and Saunders 2001; Baird and Dearden 2003; Naughton-Treves et al. 2005). However, in many cases simply setting aside PAs does not produce the positive conservation outcomes expected, due to their purely ecological focus and exclusion (or low recognition) of local rights and practices (Ghimire and Pimbert 1997; Mukul and Quazi 2009). In fact, in developing nations local communities obtain a large proportion of their livelihoods from forests (Gadgil 1990; Bahuguna 2000) and are most vulnerable to the establishment of PAs, since, by definition, PAs imply restricted use of resources (Hales 1989). Such insecurities (or conflicts of interest), together with higher population densities and relatively lower per capita income, also makes the maintenance of PAs one of the most critical issue in many regions (Nepal and Weber 1995; Hedge and Enters 2000; Badola and Hussain 2003; Mbile et al. 2005; Laurance 2007).

Non-timber forest products (NTFPs), due to their perceived renewable nature, are viewed as a potential means to enhance rural livelihoods and conserve biodiversity in many forested regions across the world (Ros-Tonen et al. 1995; Uma Shankar et al. 1996, 2001; Hegde et al. 1996; Bawa and Gadgil 1997). In recent years, the contribution of NTFPs to alleviating poverty, particularly in the developing world, has been widely recognized (Iqbal 1993; Shackleton et al. 2005; Rasul et al. 2008). Realizing their potential, NTFP extraction, together with improved market facilities, has also been promoted by conservationists, development organizations and, more recently, by governments, as a 
strategy to improve rural livelihoods in an environmentally sound way (Belcher et al. 2005; Gubbi and MacMillan 2008). The main assumptions behind these ideas are that NTFP harvesting is more benign than timber harvesting (Myers 1988), and increasing the value of NTFPs earned by local people provides incentives for conservation of forests (Plotkin and Famolare 1992; Evans 1993). Recognizing NTFPs crucial role in the livelihood of traditional forest dwellers, the government of India has recently approved collection by local communities, even from PAs (Gubbi and MacMillan 2008). In Bangladesh, with extreme population pressure and low per capita income, NTFPs play a significant role in the life and livelihood of millions of ultra-poor people living in countryside (Basit 1995). The country also has one of the lowest per capita PA coverages and currently, as a response to various environmental concerns, is expanding its land under PA networks (Mukul 2007a). However, due to poor recognition of customary forest use and practice, many of these PAs are not supported by local inhabitants (Mukul et al. 2008). We assume that NTFP collection, if legally permitted and properly managed, could be a great way for balancing livelihoods and conservation in Bangladesh PAs. Our present study therefore aimed to investigate stakeholder understanding of NTFPs, their harvesting, sustainability issues, prospective role in conservation within PAs and their present contribution to household livelihoods. The study should help to elucidate the people-PA conflicts in developing countries and, most importantly, understand local perceptions on
NTFPs and the urgency of legal recognition of NTFP harvesting from PAs, under certain conditions.

\section{Materials and methods}

\section{Study site}

The study was performed in Satchari National Park (managed under IUCN PA Management Category V), one of four PAs in the northeast of Bangladesh (Mukul 2007a). The national park is also one of the youngest PAs (amongst a total of 18) in the country. The name of the park, Satchari, comes from 'seven streams', locally named chara, referring to streams that flow through the forest (NSP 2006). Before government ratification as a PA in 2005, the park was part of the Raghunandan Hills Reserve Forest (RF) within the Satchari Range (Mukul et al. 2007). The topography of the park is undulating, with slopes and hillocks, locally called tilla, ranging from 10 to $50 \mathrm{~m}$ asl. The yearly average rainfall of the area is $4162 \mathrm{~mm}$, with May and October being the hottest months, and average maximum temperature around $32^{\circ} \mathrm{C}$, with January being the coldest month, when the temperature falls to about $12^{\circ} \mathrm{C}$ (Choudhury et al. 2004). The area of the park is 242.83 ha (compared to the total reserve area of $1760 \mathrm{ha}$ ), has remnants of biologically rich forests, is located in the high rainfall biogeographic zone, and has a multi-tier vegetation assemblage (NSP 2006). Originally, the park was under bioecological zone $9 \mathrm{~b}$ Sylhet Hills (Nishat et al. 2002). The park supports mixed tropical evergreen forests that have been substantially

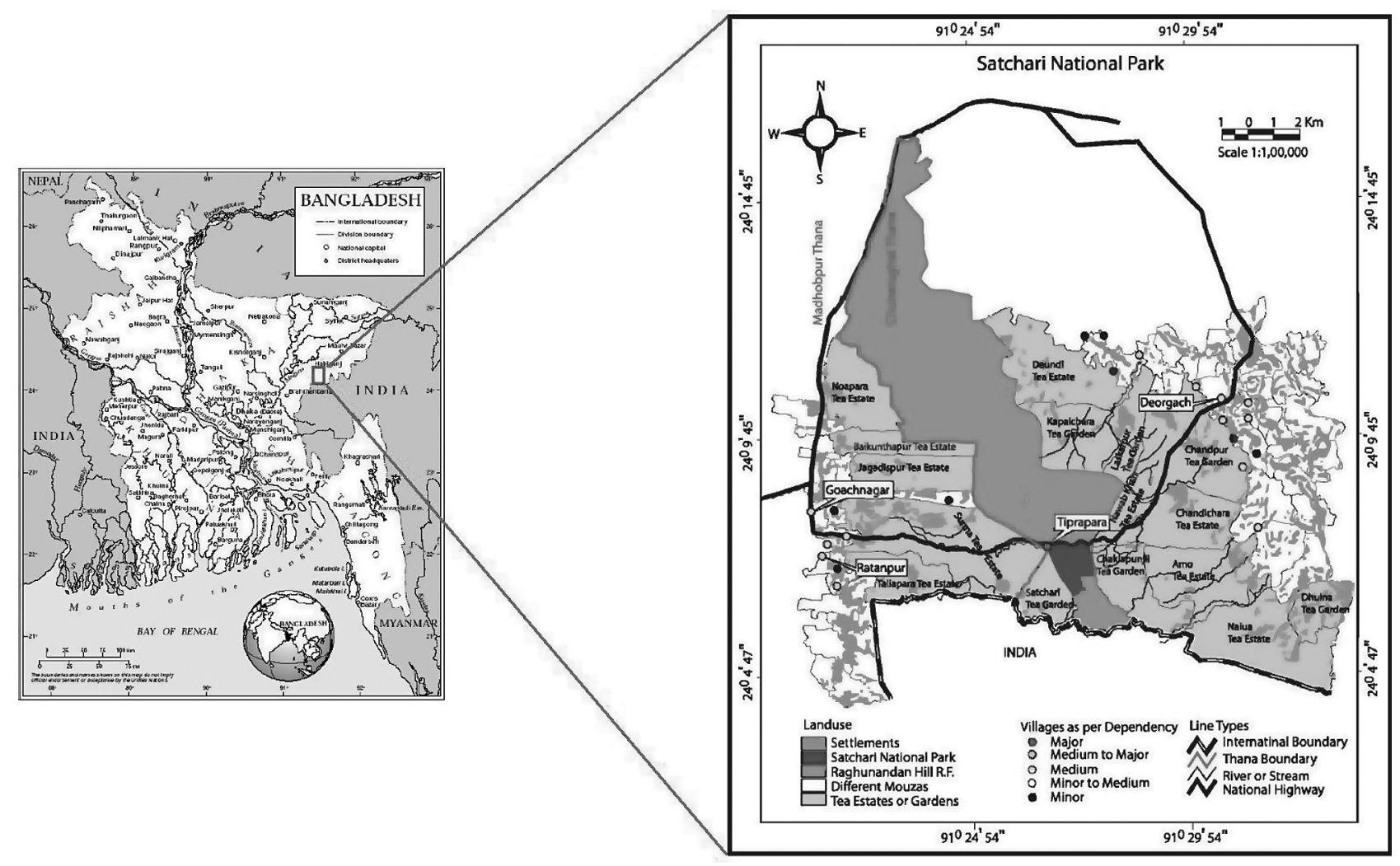

Figure 1. Map of the study site with respective village locations. 
altered over the years due to heavy biotic interference and plantation establishment, followed by clear-felling of natural vegetation (Choudhury et al. 2004). Administratively, the park is located in Chunarughat Upazilla of Habiganj district and is $130 \mathrm{~km}$ northeast of Dhaka. India borders the park on its southern side (Figure 1). Adjacent areas are covered with tea estates, rubber gardens, agar (Aquilaria) plantations and paddy fields (Feeroz 2003). The park on the east and west sides is surrounded by tea estates, and on north and south sides by portions of the Raghunandan Hill Reserve Forest, only a few villages are located in the immediate vicinity of the park (Figure 1).

\section{Selection of the villages}

A total of 19 villages having varied interests in the national park and the surrounding RF have so far been identified (Mollah et al. 2004). Of these, only the village inside the park inhabited by the ethnic Tripura tribe is considered a forest village, because of their great dependency on the park. The other settlements having a stake in the national park are located $2-8 \mathrm{~km}$ from it (Figure 1). For the study, we randomly selected four villages from a list of villages representing different levels of park dependency (i.e. major, medium to major, medium and minor to medium). Among the villages, Tiprapara was the only village having a major stake in the national park and was selected for its uniqueness. Other villages selected were Ratanpur (medium to major dependency), Deorgach (medium dependency) and Goachnagar (minor to medium dependency).

\section{Field techniques and sampling}

We arranged several focus group discussions (FGD) and community mapping exercises in each of the selected villages to obtain insights into the villages, their community organisation, power structures, resource background, patterns and perceived extent of forest dependency, and historical perspective on the surrounding forests. During the period, we also prepared a list of households for each village and ranked them into three divergent forest dependency categories, viz major, moderate and least forest dependent, based on the value and extent of their forest products use. The approximate value of forest products used (for consumption or sale) annually by households in these three forest dependency categories were fixed respectively as, $>\mathrm{Tk}^{1}$ 54,000, Tk 24,000-54,000 and $>$ Tk 24,000. From each of these forest dependency categories we interviewed $10 \%$ of households (one knowledgeable respondent for each identified household) by adopting a stratified random sampling approach. In Tiprapara, however, we took a 100\% sample due to its relatively small population size $(n=21)$ and close relationship with the national park.

\section{Data collection and analysis}

We collected both qualitative and quantitative data through a series of intensive field surveys undertaken between early 2006 and early 2007 in the identified villages.
A semi-structured questionnaire was used for household survey, where all the background information of the households (i.e. socio-economic and demographic status), relative contribution of forests to their livelihoods, harvested NTFPs, collection patterns and economic importance, understanding of possible ecological impacts, conservation potential and other relevant issues were noted. On each topic respondents were encouraged to express their independent views. Various methods have been developed for assessing the income and dependency of households on forests (e.g. Wollenberg 2000; IIED 2003). For valuing forest NTFPs used by households, we adopted the following formula as per Ambrose-Oji (2003):

Net Forest Income: Direct cash benefits from selling all harvested forest products (revenue) + Market value of the consumed forest products that residents may otherwise have purchased from the market (savings) - Investment cost/ Opportunity cost.

\section{Results}

\section{General information}

Approximately $37 \%$ of households in our sample villages were extremely poor (monthly income $>$ Tk 2000), followed by medium to poor (32\%; income Tk 2000-7500 per month) or rich (31\%; monthly income $>$ Tk 7500). Literacy among the villages was about $54 \%$, comprising mostly children in continuing education and at school. Observed primary occupations across the villages were agriculture, mainly paddy cultivation (37\%), followed by NTFP extraction (18\%), illegal timber poaching (18\%), day labour $(15 \%)$, small business $(5 \%)$, public and private services $(4 \%)$ and overseas employment $(2 \%)$.

In Satchari, around $13 \%$ of households in the sample villages were totally forest-dependent; the remaining households were least or moderately dependent on the surrounding forests for their livelihoods. Tiprapara, the only village inside the PA, was established by the Forest Department (FD) to provide labour for raising plantations after clear-felling of natural forests. Since they are living formally in the park, almost all Tripura households maintain a very special relation with the forests, and enjoy limited land for their settlement and for traditional lemon cultivation within the park area. They also had informal permission to collect NTFPs from forests (mainly firewood and housing material) for their own use. Some Tripura young people also serve the FD on a voluntary basis for patrolling the surrounding forests. Table 1 provides a brief profile of the sample villages.

\section{NTFPs in the livelihoods and income of villagers}

Overall, collection and trading in NTFPs constituted about $19 \%$ of total earnings in the study villages. Other major income-generating activities were agriculture (30\%), business $(21 \%)$ and timber poaching (11\%). Our survey also revealed 13 major NTFPs in the area that have regularly 
Table 1. Profile of the study villages.

\begin{tabular}{|c|c|c|c|c|}
\hline Village & $\begin{array}{l}\text { Location and distance } \\
\text { (approx.) }\end{array}$ & $\begin{array}{l}\text { Population } \\
\text { Size (HHs) }\end{array}$ & $\begin{array}{c}\text { Forest } \\
\text { dependency }\end{array}$ & Forest practices \\
\hline Tiprapara & Inside $(0 \mathrm{~km})$ & $22(n=22)$ & Major & $\begin{array}{l}\text { Collect firewood, house-building material, fruit and other NTFPs, } \\
\text { cultivate lemon and others trees }\end{array}$ \\
\hline Ratanpur & Outside $(2.5 \mathrm{~km})$ & $156(n=16)$ & Medium to major & Mainly involved with illegal tree felling and collecting firewood \\
\hline Deorgach & Outside east $(3 \mathrm{~km})$ & $316(n=31)$ & Medium & Mainly collect firewood, some involved with illegal tree felling \\
\hline Goachnagar & Outside west $(3.5 \mathrm{~km})$ & $328(n=32)$ & Medium to minor & Mainly collect firewood, some involved with illegal tree felling \\
\hline
\end{tabular}

Source: Field survey 2006-2007.

been collected by local villagers from nearby forests (i.e. SNP and surrounding RF) (Table 2). However, only a few of these made a significant contribution to household incomes. Mainly five NTFPs, firewood, medicinal bark of menda (to prepare mosquito repellent), taragota (a substitute for cardamom), kumbi leaf (used to wrap tobacco) and bamboo account for more than $90 \%$ of NTFP-based income in the area. Collection of these key NTFPs by villagers, however, was not uniform across the villages. All households from Tiprapara collected firewood from nearby forests (mainly from SNP), while households from Ratanpur, Deorgach and Goachnagar collected firewood at percentages of $60 \%, 55 \%$ and $56 \%$, respectively (mainly from RF). Menda bark was mostly collected and traded by villagers from Deorgach, and taragota was collected mostly by people from Ratanpur. In addition, day labourers from all the study villages also collected firewood on their days off (mainly during agricultural off periods).

\section{Source, extent and harvesting patterns of key NTFPs}

Table 2 presents a comprehensive listing of NTFPs of Satchari area, with origin, major sources, collection extent, perceived stock and future possibility for development. Firewood was the most extensively collected NTFP in the area, where bamboo, taragota, kumbi leaf, menda bark, broom grass, rattan and sun grass are harvested moderately by local settlers. The PA also served as the major source of eight important NTFPs for the villagers, including three NTFPs collected only from the national park. In the PA, stocks of several NTFPs, bamboo, broom grass and taragota, were reported as satisfactory by the villagers.

Households maintain a seasonal/alternative schedule for collection of major NTFPs in Satchari area. Most of the NTFPs were collected annually, mostly during the monsoon. Other NTFPs (bamboos and firewood) were collected biannually or on a regular basis (Table 3). A generalized harvesting calendar for major NTFPs of Satchari area, with the harvesting intensity is given in Table 4. Villagers claimed that only in a few cases did NTFP harvesting involve collection of whole plants. People usually uprooted whole plants while collection of taragota and/or firewood. In other cases, they collected either upper parts (upper stem for bamboos) of the plants or only leaves. For menda bark, they generally collected only mature bark from the tree trunk.

Table 2. NTFPs collected from SNP and adjoining forests by the households.

\begin{tabular}{|c|c|c|c|c|c|c|}
\hline NTFPs & $\begin{array}{l}\text { Local/Trade } \\
\text { name }\end{array}$ & Biological origin & Source $^{\mathrm{a}}$ & $\begin{array}{l}\text { Extent of } \\
\text { collection }\end{array}$ & $\begin{array}{l}\text { Present } \\
\text { stock }^{\mathrm{b}}\end{array}$ & $\begin{array}{c}\text { Future } \\
\text { potential }^{\mathrm{b}}\end{array}$ \\
\hline Bamboo & Bansh & $\begin{array}{l}\text { Bambusa vulgaris Schard. } \\
\text { Melocanna baccifera Roxb. }\end{array}$ & $\mathrm{RF}, \mathrm{NP}$ & Medium & High & High \\
\hline Broom grass & Phul jharu & Thysanolaena maxima Roxb. & NP & Medium & High & Medium \\
\hline Bush meat & - & Various species & $\mathrm{NP}, \mathrm{RF}$ & Very low & Low & Very low \\
\hline Firewood & Zalani/Lakri & All woody species & $\mathrm{NP}, \mathrm{RF}$ & High & Medium & High \\
\hline Forage and fodder & - & Various species & RF & Low & High & Very low \\
\hline Fruits & Phal-mul & $\begin{array}{l}\text { Artocarpus heterophyllus Lamk. } \\
\text { A. chaplasha Roxb. } \\
\text { A. lakoocha Roxb. } \\
\text { Citrus limon } \mathrm{L} \text {. } \\
\text { Syzygium spp. }\end{array}$ & $\mathrm{NP}, \mathrm{RF}$ & Low & Medium & Low \\
\hline Honey & Modhu & $\begin{array}{l}\text { Apis florae } \\
\text { Apis dorsata }\end{array}$ & RF, NP & Very low & Low & Medium \\
\hline Wrapping leaf & Kumbi pata & Careya arborea Roxb. & NP & Medium & Low & Low \\
\hline Medicinal plants & Banoushodhi & Various species & $\mathrm{NP}, \mathrm{RF}$ & Low & High & High \\
\hline Sticky bark & Menda & Litsea monopetala (Roxb.) Pers. & $\mathrm{NP}, \mathrm{RF}$ & Medium & Medium & High \\
\hline Rattan & Bet & $\begin{array}{l}\text { Calamus guruba Ham. } \\
\text { Daemonorops jenkensianus Mart. }\end{array}$ & $\mathrm{RF}, \mathrm{NP}$ & Low & Medium & High \\
\hline Sun grass & Shan ghass & Imperata cylindrica $\mathrm{L}$. & RF, NP & Medium & High & Low \\
\hline Wild cardamom & Taragota & Amomum sabulatum Roxb. & NP & Medium & High & High \\
\hline
\end{tabular}

Note: 'NP, national park; RF, reserved forest; sequence indicates where the major harvesting operation took place. ${ }^{\mathrm{b}}$ Based on peoples' perceptions. 
Table 3. Pattern of and possible impacts of key NTFPs harvesting.

\begin{tabular}{llllll}
\hline NTFPs & Frequency of collection & Usable parts & Harvested parts & Recovery rate $^{\text {a }}$ & Possible impacts $^{\text {a }}$ \\
\hline Bamboo & Frequent & Culm & Upper stem & Moderate & Medium \\
Broom grass & Annual & Inflorescence & Upper part & Satisfactory & Low \\
Firewood & Frequent & Whole plant & Whole plant & $?$ & $?$ \\
Kumbi leaf & Annual & Leaves & Laves & Satisfactory & Low \\
Menda bark & Annual & Bark & Bark (by side) & $?$ & Medium \\
Rattan & Annual & Upper stem & Upper part & Satisfactory & Low \\
Sun grass & Annual & Leaves & Leaves & Satisfactory & Low \\
Taragota & Annual & Rhizome & Whole plant & Moderate & Medium \\
\hline
\end{tabular}

Note: 'Based on respondents' perceptions.

Table 4. Harvesting schedule of major NTFPs in the area.

\begin{tabular}{|c|c|c|c|c|c|c|c|c|c|c|c|c|}
\hline \multirow{2}{*}{$\begin{array}{l}\text { Non-timber forest } \\
\text { product }\end{array}$} & \multicolumn{12}{|c|}{ Month of harvesting activity } \\
\hline & Jan & Feb & Mar & Apr & May & Jun & Jul & Aug & Sep & Oct & Nov & Dec \\
\hline \multicolumn{13}{|l|}{ Wood fuel } \\
\hline \multicolumn{13}{|l|}{ Menda bark } \\
\hline \multicolumn{13}{|l|}{ Taragota } \\
\hline \multicolumn{13}{|l|}{ Kumbi leaf } \\
\hline Bamboo & & & & & & & & & & & & \\
\hline
\end{tabular}

Note: Light color indicates lower amount harvested and vice-versa.

Our survey indicated some possible NTFPs for local development in the Satchari area (Table 2), even though this was not always coherent with harvesting patterns and/or current stocks in the forest. Households perceived that the recovery rate after harvesting of bamboo, taragota, kumbi leaf, rattan, broom grass and sun-grass in the forest were moderate to satisfactory, although for menda bark and firewood this was somewhat questionable. The possible impacts of harvesting these NTFPs on overall future production and stocks in the forests were medium to low, according to the respondents (Table 3 ).

\section{Household consensus on potentials and sustainability of NTFPs}

Our survey revealed that about $76 \%$ of households in the area understood the concept and necessity of conservation in the PA. Moreover, around $96 \%$ of respondents had clear ideas about NTFPs, although their responses on advanced issues related to ecology and management of NTFPs were limited and positively influenced by social and/or educational background. Around $66 \%$ of respondents believed that NTFPs could play a strong positive role in conservation through providing alternative income opportunities to rural forest-dependent people who may otherwise engaged in illegal logging or other destructive forest activities.

Table 5 summarizes the overall response of our interviewees on specific questions related to ecology and management of NTFPs in Satchari area. In total, $71 \%$ of respondents had some understanding of possible ecological impacts of NTFP harvesting, and $60 \%$ considered the present NTFP harvesting schemes ecologically feasible.
Again, $42 \%$ of respondents believed that overall management of NTFPs in the area was sustainable, i.e. sufficient to recover the stock of NTFPs on the forest floor and with little or no impact on future productivity. About 38\% of respondents also claimed that stocks of different NTFPs in Satchari area had remained unchanged for years following the present management and harvesting schemes, while 33\% reported a negative trend in overall NTFP stock. Almost half $(48 \%)$ of respondents believed that NTFPs could play a positive role in balancing livelihoods and conservation in PAs, while $22 \%$ believed that NTFP potential was low and limited by factors such as market insecurity and lack of proper marketing channels. Again, when asked about managerial issues, 36\% of respondents replied that even if given a legal basis for NTFP harvesting from the PA, monitoring should be the collectors responsibility, while $46 \%$ voted for a communal management system.

\section{Discussion and conclusions}

The extraction of NTFPs is a very common and well recognized way of sustaining local livelihoods throughout the world (Iqbal 1993; de Beer and McDermott 1996; Arnold and Ruiz Perez 1998; Hedge and Enters 2000; Wunder 2000; Angelsen and Wunder 2003; Shackleton and Shackleton 2004; Ticktin 2004; Das 2005; Mahapapatra et al. 2005; Rasul et al. 2008) and sustainable harvesting of NTFPs is now advocated as ecologically, economically and culturally better forest practice (Uma Shankar et al. 2001; Shackleton et al. 2005), even though the sustainability has rarely been empirically tested, particularly in the case of PAs (Arnold and Ruiz Pérez 2001; Shahabuddin and 
Table 5. Households' responses on issues related to ecology and management of NTFPs.

\begin{tabular}{|c|c|c|c|c|c|}
\hline \multirow[b]{2}{*}{ Issue/question } & \multicolumn{5}{|c|}{ No. of respondents } \\
\hline & Tiprapara & Ratanpur & Deorgach & Goachnagar & Total \\
\hline \multicolumn{6}{|c|}{ Household understanding on ecological impact of NTFP harvesting } \\
\hline Present & $17(77.3)$ & $12(75.0)$ & $23(74.2)$ & $20(62.5)$ & $72(71.3)$ \\
\hline Absent & $5(22.7)$ & $4(25.0)$ & $8(25.8)$ & $12(37.5)$ & $29(28.7)$ \\
\hline \multicolumn{6}{|c|}{ 'Are present NTFP harvesting techniques ecologically sound?' } \\
\hline Yes & $14(63.6)$ & $11(68.7)$ & $18(58.0)$ & $18(56.2)$ & $61(60.4)$ \\
\hline No & $3(13.6)$ & $1(6.3)$ & $3(9.7)$ & $3(9.4)$ & $10(9.9)$ \\
\hline No comment & $5(22.7)$ & $4(25.0)$ & $10(32.3)$ & $11(34.4)$ & $30(29.7)$ \\
\hline \multicolumn{6}{|c|}{ Household opinion on overall sustainability of present NTFP management } \\
\hline Sustainable & $8(36.3)$ & $9(56.3)$ & $14(45.2)$ & $11(34.4)$ & $42(41.6)$ \\
\hline Unsustainable & $4(18.2)$ & - & $4(12.9)$ & $3(9.4)$ & $11(10.9)$ \\
\hline No comment & $10(45.5)$ & $7(43.7)$ & $13(41.9)$ & $18(56.2)$ & $48(47.5)$ \\
\hline \multicolumn{6}{|l|}{ Historical change in local NTFP stocks } \\
\hline Increased & $9(40.9)$ & $5(31.25)$ & $8(25.8)$ & $8(25.0)$ & $30(29.7)$ \\
\hline Decreased & $6(27.3)$ & $5(31.25)$ & $9(29.0)$ & $13(40.6)$ & $33(32.7)$ \\
\hline No change & $7(31.8)$ & $6(37.5)$ & $14(45.2)$ & $11(34.4)$ & $38(37.6)$ \\
\hline \multicolumn{6}{|c|}{ Households believe 'promotion of NTFPs could balance livelihoods and conservation in PAs' } \\
\hline Positive & $10(45.4)$ & $9(56.2)$ & $14(45.2)$ & $15(46.9)$ & $48(47.5)$ \\
\hline Negative & $4(18.2)$ & $2(12.5)$ & $7(22.6)$ & $9(28.1)$ & $22(21.8)$ \\
\hline No idea & $8(36.4)$ & $5(31.3)$ & $10(32.2)$ & $8(25.0)$ & $31(30.7)$ \\
\hline \multicolumn{6}{|c|}{ Household thoughts on possible basis of monitoring scheme of NTFP harvesting } \\
\hline Self responsibility & $6(27.3)$ & $5(31.25)$ & $14(45.2)$ & $11(34.4)$ & $36(35.7)$ \\
\hline Communal monitoring arrangement & $11(50.0)$ & $9(56.25)$ & $10(32.2)$ & $17(53.1)$ & $47(46.5)$ \\
\hline FD and Park Manager & $5(22.7)$ & $2(12.5)$ & $7(22.6)$ & $4(12.5)$ & $18(17.8)$ \\
\hline
\end{tabular}

Note: Values in parentheses indicate percentage of total population under corresponding group/sub-group.

Prasad 2004; Ticktin 2004; Gubbi and MacMillan 2008). Our study clearly suggests that NTFPs play a crucial role in the life and livelihoods of rural forest-dependent people in Satchari area; providing full-time or seasonal employment to about $18 \%$ of households, and worth $19 \%$ of total cash generated in the area. In both cases, although the contribution of NTFPs was not large, it was very important, mostly for poorer households who directly or indirectly benefit from collection and trading (Dove 1993; Das 2005) and for those who were undoubtedly most vulnerable in this area. The scenario is not atypical in many other tropical developing countries, even in PAs where access to collect NTFPs has either been denied or is restricted to safeguard forest biodiversity (Hedge and Enters 2000; Ticktin et al. 2002; Das 2005; Gubbi and MacMillan 2008), but the extent and distribution of benefits differ (Hedge and Enters 2000; Ambrose-Oji 2003) and not all people are keen to continue such a life if alternatives are provided or available (Badola 1998; Silori 2007). Arjunan et al. (2005) and Gubbi and MacMillan (2008) concluded that NTFP harvesting is unlikely to generate positive conservation outcomes and/or economic upliftment in PAs, and legal recognition of local NTFP harvesting from PAs may have negative impact on biodiversity. In contrast to their findings, the local households of Satchari area hold a very positive view about the prospective role of NTFPs in conservation, particularly in PAs (Mukul 2007b). Local ecological knowledge (71\% household) and household views on sustainability (53\%) was also appreciable, coherent with their traditional harvesting patterns and seasonal provisions to allow most NTFPs adequate time and space to rejuvenate in the forest.
Some potential key constraints and challenges to the success of NTFPs-based conservation strategies experienced in many parts of the world are resource supply and sustainability (Peters 1996; Ticktin 2004), as well as processing and marketing (Belcher et al. 2005). Although households believed that the first two issues are met by the present NTFP management and collection schemes, they need to be properly tested and ensured. Again, promotion of commercial extraction of NTFPs as a conservation strategy is principally based on the argument that NTFPs could provide economic incentives to rural people who may otherwise be involved in destructive forest practices such as illegal logging or cattle ranching (Nepstad and Schwartzman 1992; Plotkin and Famolare 1992). Some recent experience, however, suggests that the production and estimation of sustainable harvesting levels of locally useful NTFPs are frequently an afterthought, and rapid commercialization potentially leads to over-exploitation or depletion of such NTFPs (Neumann and Hirsch 2000; Belcher et al. 2005), which can even lead to total local extinction of a NTFP (or reduced NTFP yield of a plant/animal) or wide-scale degradation of the forest landscape/habitat (Ganeshaiah et al. 1998, Uma Shaanker et al. 2004). It is therefore another important challenge to determine an ecologically feasible sustainable harvesting level of key NTFPs, as well as their proper maintenance and monitoring in the forests.

In general, our research concludes that NTFPs provide a significant part of household livelihoods and income, even in PAs, and households place a high value on their conservation potential. Households also believed that the present NTFP schemes are ecologically benign or less harmful, but further investigations are required to assess the ecological 
compatibility of traditional harvesting practices at the field level. It is also important to clarify the socio-economic and political factors affecting the success or failure of NTFP development and promotion, which are presumably similar in most developing regions. Finally, despite their great importance and value to livelihoods and income of marginal forest communities, most conservation agencies still exclude this opportunity from their regular conservation activities/strategies particularly designed for PAs. In some cases, although collection of some NTFPs is unofficially approved (by intentionally overlooking), official recognition through legislation is vital to properly utilize this opportunity and ensure the sustainable harvesting limit is followed.

\section{Acknowledgements}

The study was partially funded by USAID through a joint fellowship programme of the East-West Center, Hawaii and Nishorgo Support Project of Bangladesh Forest Department. We are grateful to Mr Tito, Mr Nobel and Mr Pranto for their friendly support in our fieldwork. Thanks also to Ms Shimona Quazi for feedback on an earlier version of this manuscript. Finally, we are grateful to our respondents for sharing their valuable knowledge on NTFPs, their use, ecology and management.

\section{Note}

1. Tk or Taka, Bangladeshi currency; exchange rate with US\$1 during the study period was about $69.5 \mathrm{Tk}$.

\section{References}

Abakerli S. 2001. A critique of development and conservation policies in environmentally sensitive regions of Brazil. Geoforum. 32(2001):551-565.

Ambrose-Oji B. 2003. The contribution of NTFPs to the livelihoods of the 'forest poor': evidence from the tropical forest zone of south-west Cameroon. Int For Rev. 5(2):106-117.

Angelsen A, Wunder S. 2003. Exploring the forest-poverty link: key concepts, issues and research implications. Bogor (Indonesia): Center for International Forestry Research (CIFOR). CIFOR Occasional Paper No. 40.

Arjunan M, Puyravaud JP, Davidar P. 2005. The impact of resource collection by local communities on the dry forests of the Kalakad-Mundanthuri Tiger Reserve. Trop Ecol. 46(2):135-143.

Arnold JEM, Ruiz Perez M. 1998. The role of non-timber forest products in conservation and development. In: Wollenberg E, Ingles $\mathrm{A}$, editors. Incomes from the forest, methods for the conservation and development of forest products for local communities. Borgor (Indonesia): Centre for International Forestry Research (CIFOR). p. 17-42.

Arnold JEM, Ruiz Pérez M. 2001. Can non-timber forest products match tropical forest conservation and development objectives? Ecol Econ. 39(3):437-447.

Badola R. 1998. Attitudes of local people towards conservation and alternatives to forest resources: a case study from the lower Himalayas. Biodivers Conserv. 7:1245-1259.

Badola R, Hussain SA. 2003. Conflict in paradise: women and protected areas in the Indian Himalayas. Mt Res Dev. 23(3):234-237.

Bahuguna VK. 2000. Forests in the economy of rural poor: an estimation of the dependency level. Ambio. 29(3):126-129.
Baird IG, Dearden P. 2003. Biodiversity conservation and resource tenure regimes: a case study from northeast Cambodia. Environ Manage. 32(5):541-550.

Basit MA. 1995. Non-wood forest products from the Mangrove Forests of Bangladesh. In: Durst PB, Bishop A, editors. Beyond timber: social, economic and cultural dimensions of non-wood forest products in Asia and the Pacific. Proceedings of a regional expert consultation held in Bangkok, Nov 28 to 1994 Dec 2. Bangkok (Thailand): FAO Regional Office for Asia and the Pacific (FAO-RAP). p. 193-200.

Bawa KS, Gadgil M. 1997. Ecosystem services, subsistence economies and conservation of biodiversity. In: Daily G, editor. Nature's services: societal dependence on natural systems. Washington (DC): Island Press. p. 295-310.

Belcher B, Ruiz-Pérez M, Achdiawan R. 2005. Global patterns and trends in the use and management of commercial NTFPs: implications for livelihoods and conservation. World Dev. 33(9):1435-1452.

Chape S, Blyth S, Fish L, Fox P, Spalding M, editors. 2003. United Nations list of protected areas. Gland (Switzerland): IUCN. Cambridge (UK): UNEP-WCMC.

Choudhury JK, Biswas SR, Islam MS, Rahman O, Uddin SN. 2004. Biodiversity of Satchari Reserved Forest, Habiganj. Dhaka (Bangladesh): IUCN Bangladesh Country Office.

Clerici N, Bodini A, Eva H, Gregoire J, Dulieu D, Paolini C. 2007. Increased isolation of two biosphere reserves and surrounding protected areas (WAP ecological complex, West Africa). J Nat Conserv. 15:26-40.

Das BK. 2005. Role of NTFPs among forest villagers in a protected area of West Bengal. J Hum Ecol. 18(2):129-136.

de Beer JH, McDermott MJ. 1996. The economic value of non-timber forest products in Southeast Asia. 2nd ed. Amsterdam (The Netherlands): Netherlands Committee for IUCN.

DeFries R, Hansen A, Turner BL, Reid R, Liu J. 2007. Land use change around protected areas: management to balance human needs and ecological function. Ecol Appl. 17(4):1031-1038.

Dove MR. 1993. A revisionist view of tropical deforestation and development. Environ Conserv. 20(1):17-24.

Evans MI. 1993. Conservation by commercialization. In: Hladik CM, Hladik A, Linares OF, Pagezy H, Semple A, Hadley M, editors. Tropical forests, people and food: bio-cultural interactions and applications to development. Paris (France): UNESCO. p. 815-822. (MAB series; Vol. 13).

Feeroz MM. 2003. Wildlife diversity in Satchari forest of north-eastern region of Bangladesh. Bangladesh J Life Sci. 15(1):61-76.

Gadgil M. 1990. India's deforestation: patterns and processes. Soc Nat Resour. 3:131-141.

Ganeshaiah KN, Uma Shaanker R, Murali KS, Shanker U, Bawa KS. 1998. Extraction of non-timber forest products in the forests of Biligiri Rangan Hills. 5. Influence of dispersal mode on species response to anthropogenic pressures. Econ Bot. 52:316-319.

Ghimire KB. 1994. Parks and people: livelihood issues in national parks management in Thailand and Madagascar. Dev Change. 25:195-229.

Ghimire KB, Pimbert MP. 1997. Social change and conservation: an overview of issues and concepts. In: Ghimire KB, Pimbert MP, editors. Social change and conservation: environmental politics and impacts of national parks and protected areas. London (UK): Earthscan. p. 1-45.

Gubbi S, MacMillan DC. 2008. Can non-timber forest products solve livelihood problems? A case study from Periyar Tiger Reserve, India. Oryx. 42(2):222-228.

Hales D. 1989. Changing concepts of national parks. In: Western $\mathrm{D}$, Pearl M, editors. Conservation for the Twenty-first Century. Oxford (UK): Oxford University Press. 
Hegde R, Enters T. 2000. Forest products and household economy: a case study from Mudumalai Wildlife Sanctuary, Southern India. Environ Conserv. 27(3):250-259.

Hegde R, Suryaprakash S, Achoth L, Bawa KS. 1996. Extraction of non-timber forest products in the forest of Biligiri Rangan Hills, India. 1. Contribution to rural income. Econ Bot. 50:243-251.

[IIED] International Institute for Environment and Development. 2003. Valuing forests: a review of methods and applications in developing countries. Environmental Economics Programme. London (UK): International Institute for Environment and Development (IIED).

[IUCN] The World Conservation Union. 1994. Guidelines for protected area management categories. Cambridge (UK): The World Conservation Union (IUCN).

Iqbal M. 1993. International trade in non-wood forest products: an overview. Rome (Italy): Food and Agriculture Organization (FAO).

Kaimowitz D, Sheil D. 2007. Conserving what and for whom? Why conservation should help meet basic human needs in the tropics. Biotropica. 39(5):567-574.

Koziell I, Saunders J, editors. 2001. Living off biodiversity: exploring livelihoods and biodiversity. London (UK): International Institute for Environment and Development (IIED).

Laurance WF. 2007. Forest destruction in tropical Asia. Curr Sci. 93(11):1544-1550.

Mahapapatra AK, Albers HJ, Robinson EJZ. 2005. The impact of NTFP sales on rural households' cash income in India's dry deciduous forest. Environ Manage. 35(3):258-265.

Mbile P, Vabi M, Meboka M, Okon D, Arrey-Mbo J, Nkongho F, Ebong E. 2005. Linking management and livelihood in environmental conservation: case of the Korup National Park Cameroon. J Environ Manage. 76(2005):1-13.

McNeely J, Scherr S. 2003. Ecoagriculture: strategies to feed the world and conserve wild biodiversity. Washington (DC): Island Press.

Mollah AR, Kundu DK, Rahman MM. 2004. Site-level field appraisal for protected area co-management: Satchari Reserve Forest. Dhaka (Bangladesh): Nature Conservation and Management (NACOM).

Mukul SA. 2007a. Biodiversity conservation strategies in Bangladesh: the state of protected areas. Tigerpaper. 34(3):28-32.

Mukul SA. 2007b. Bridging livelihoods and forest conservation in protected areas: exploring the role and scope of non-timber forest products. Field experience from Satchari National Park, Habiganj, Bangladesh [BSc. dissertation]. Sylhet (Bangladesh): Shahjalal University of Science and Technology.

Mukul SA, Quazi SA. 2009. Communities in conservation: changing protected area management and enhanced conservation in Bangladesh. In: Lesile RN, editor. Proceedings of the international conference; 'The Future of Forests in Asia and the Pacific: Outlook for 2020' held in 2007 Oct 16-18 at, Chiang Mai (Thailand). p. 143-159.

Mukul SA, Uddin MB, Tito MR. 2007. Medicinal plant diversity and local healthcare among the people living in and around a conservation area of northern Bangladesh. Int J For Usufructs Manage. 8(2):50-63.

Mukul SA, Uddin MB, Uddin MS, Khan MASA, Marzan B. 2008. Protected areas of Bangladesh: current status and efficacy for biodiversity conservation. Proc Pakistan Acad Sci. 45(2):59-68.

Mulongoy KJ, Chape SP, editors. 2004. Protected areas and biodiversity: an overview of key issues. Montreal (Canada): CBD Secretariat. Cambridge (UK): UNEP-WCMC.

Myers N. 1988. Tropical forests: much more than stocks of wood. J Trop Ecol. 4:209-221.

Nagothu US. 2003. Local people's attitudes towards conservation and wildlife around Sariska Tiger Reserve, India. J Environ Manage. 69:339-347.
Naughton-Treves L, Holland MB, Brandon K. 2005. The role of protected areas in conserving biodiversity and sustaining local livelihoods. Annu Rev Environ Resour. 30:219-252.

Nepal SK, Weber KE. 1995. Managing resources and resolving conflicts: national parks and local people. Int J Sustain Dev World Ecol. 2(1995):11-25.

Nepstad D, Schwartzman S, editors. 1992. Non-timber products from tropical forests: evaluation of a conservation and development strategy. New York (US): New York Botanical Garden. (Advances in Economic Botany; Vol. 9).

Neumann RP, Hirsch E. 2000. Commercialisation of non-timber forest products: review and analysis of research. Bogor (Indonesia): CIFOR.

Nishat A, Huq SMI, Barua SP, Reza AHMA, Khan ASM, editors. 2002. Bio-ecological zones of Bangladesh. Dhaka (Bangladesh): IUCN.

[NSP] Nishorgo Support Project. 2006. Management plans for Satchari National Park. Dhaka (Bangladesh): Nishorgo Support Project.

Ormsby A, Kaplin BA. 2005. A framework for understanding community resident perceptions on Masoala National Park, Madagascar. Environ Conserv. 32(2):156-164.

Peters CM. 1996. Observations on the sustainable exploitation of non-timber tropical forest products. In: Ruiz Perez M, Arnold JEM, editors. Current issues in non-timber forest products research. Bogor (Indonesia): CIFOR. p. 19-40.

Pimbert MP, Pretty JN. 1997. Parks, people and professionals: putting 'participation' protected-area management. In: Ghimire K, Pimbert MP, editors. Social change and conservation. London (UK): Earthscan. p. 297-330.

Plotkin MJ, Famolare LM. editors. 1992. Sustainable harvest and marketing of rainforest products. Washington (DC): Island Press.

Rasul G, Karkri M, Sah RP. 2008. The role of non-timber forest products in poverty reduction in India: prospects and problems. Dev Pract. 18(6):779-788.

Ros-Tonen M, Dijkman W, Van Bueren EL. 1995. Commercial and sustainable extraction of non-timber forest products - towards a policy and management oriented research strategy. Wageningen (The Netherlands): Tropenbos Foundation.

Scherr SJ, White A, Kaimowitz D. 2004. A new agenda for forest conservation and poverty reduction - making markets work for low-income producers. Washington (DC): Forest Trends. Bogor (Indonesia): CIFOR, Cambridge (UK): IUCN.

Shackleton CM, Guthrie G, Main R. 2005. Estimating the potential role of commercial over-harvesting in resource viability: a case study of five useful tree species in South Africa. Land Degrad Dev. 16:273-286.

Shackleton CM, Shackleton S. 2004. The importance of nontimber forest products in rural livelihood security and as safety nets: a review of evidence from South Africa. S Afr J Sci. 100:658-664.

Shahabuddin G, Prasad S. 2004. Assessing ecological sustainability of non-timber forest produce extraction: the Indian scenario. Conserv Soc. 2(2):235-250.

Silori CS. 2007. Perception of local people towards conservation of forest resources in Nanda Devi Biosphere Reserve, northwestern Himalaya, India. Biodivers Conserv. 16:211-222.

Ticktin T. 2004. The ecological implications of harvesting nontimber forest products. J Appl Ecol. 41:11-21.

Ticktin T, Nantel P, Ramirez F, Johns T. 2002. Effects of variation on harvest limits for non-timber forest species in Mexico. Conserv Biol. 16(3):691-705.

Uma Shaanker R, Ganeshaiah KN, Krishnan S, Ramya R, Meera C, Aravind NA, Kumar A, Rao D, Vanaraj G, Ramachandra J, et al. 2004. Livelihood gains and ecological costs of non-timber forest product dependence: assessing the roles of dependence, ecological knowledge and market structure in three contrasting human and 
ecological settings in south India. Environ Conserv. 31:242-253.

Uma Shankar R, Lama SD, Bawa KS. 2001. Ecology and economics of domestication of non-timber forest products: an illustration of broomgrass in Darjeeling Himalaya. J Trop For Sci. 13(1):171-191.

Uma Shankar R, Murali KS, Uma Shaanker R, Ganeshaiah KN, Bawa KS. 1996. Extraction of nontimber forest products in the forests of Biligiri Rangan Hills, India. 3.
Productivity, extraction and prospects of sustainable harvest of amla, Phyllanthus emblica (Euphorbiaceae). Econ Bot. 50:270-279.

Wells MP, McShane TO. 2004. Integrating protected area management with local needs and aspirations. Ambio. 33(8):513-519.

Wollenberg E. 2000. Methods for estimating forest income and their challenges. Soc Nat Resour. 13:777-795.

Wunder S. 2000. Poverty alleviation and tropical forests - What scope for synergies? World Dev. 29(11):1817-1833. 